service (either B-U-Y P-I-Z-A or E-A-T D-E-L-I) to the existing document delivery service via either the Food Fone or the Food Fax machines designed to look like actual food items. The fine print at the end of the Rutgers newsletter sheds a great deal of light and truth on the real purposes of all library newsletters. It "is intended to provide information about library activities and other things that no one really wants to read about. Included are such items as: announcements, pronouncements, and denouncements; lies, damned lies, and statistics; retractions, corrections and recriminations; and more meetings than you can shake a stick at. 'People in the Library'. . . notes briefly such information as marriages, divorces, affairs, births, deaths, deportations, arraignments, indictments and incarcerations; lacerations, bumps, bruises and scrapes; and addictions, afflictions and other fictions."

Always sure to produce groans, puns and similar forms of wordplay, have only a limited audience.
Fortunately there do not appear to be an inordinate number of library punsters but there are, alas, a few who deserve at least brief mention. Irving Weintraub, of the Rutgers University Library (is something going on there?), sent me a single-page sheet that contains, among other faults, the following sample of his "wit." If Harrison Ford had been a librarian he would have been searching for cataloging records rather than diamonds in Readers of the Lost MARC. The difference between a reference librarian and a rebellious youth is that one is an authority on questions and the other questions authority. Librarians usually refer to journals that represent an industry or discipline as an organ; that sometimes causes embarrassment for agricultural librarians who may refer to a journal dealing with a breed of livestock as the "breed organ." Weintraub once ended up describing a journal as "an organ for the dissemination of information on insemination."

More next time.

\title{
Adventures in grant-writing
}

\author{
By Ada D. Jarred
}

Director of Libraries

Northwestern State University of Louisiana

In a recent issue of College \& Research Libraries News, Sherman Hayes called for reports on "unique, weird services" in academic libraries. ${ }^{1}$ The librarians of Northwestern State University of Louisiana disagree somewhat with Hayes's taxonomy of activities but are nevertheless eager to share their recent adventures in writing grants.

Louisiana's depressed economic conditions over the last several years have necessitated alternative funding to maintain and enhance the core services of Eugene P. Watson Memorial Library, Northwestern State University of Louisiana. Naturally, thoughts of Northwestern librarians turned to the writing of grant proposals. Several applications proved successful, leading to the development of unusual services which have enriched the university and the surrounding area, as well as assisted with the support of core activities.

Not the least among the delights of Northwestern State University is its setting in Natchitoches (NAK-o-tish), Louisiana, the oldest continuous

${ }^{1}$ Sherman Hayes, "Wanted: Weird and/or Unusual Services and Activities," C $\measuredangle R L$ News 51 (April 1990): 322-325.
European settlement in the Louisiana Purchase and the central city of the Cane River region, a culturally diverse area of northwest Louisiana. One of the fascinating former residents of Natchitoches Parish (county) was the celebrated American author Kate Chopin, who devoted much of her writing to the people and life of this area.

In 1988 the NSU director of libraries agreed to be project director of the first international conference devoted to the life and works of Chopin. The meeting was created and planned by faculty members of the NSU Department of Languages and Communications; the NSU Louisiana Folk Life Center; the Louisiana Scholars' College, an interdisciplinary program for academically advanced university students of high ability; and the Louisiana School for Math, Science and the Arts, a residential high school for gifted and talented juniors and seniors. This was the first cooperative effort between these entities, all of whom are located on the same campus. The Association for the Preservation of Historic Natchitoches, owner and operator of the Bayou Folk Museum (housed in Chopin's former home) in nearby Cloutierville, also was a participating sponsor. 
The symposium was designed to immediately provide a scholarly forum for the examination of Chopin's fiction by scholars, teachers and the general public; offer geographical and cultural experiences of the region in parallel with Chopin's written representations of the same; and provide opportunities for dialogues about Chopin's works between readers and scholars.

Long-range goals included the enhancement of understanding and appreciation of Chopin's writings by readers and scholars; the improvement of instruction and research concerned with Chopin's writings and women's studies; increased interest in the rich literary history of the Natchitoches area; and increased understanding and support of the humanities through presentations and discussions concentrating on the life and works of one American author.

The grant proposal to the Louisiana Endowment for the Humanities was approved, and "Kate Chopin and the Cane River Region," a $2^{1 / 2}$-day conference, met on April 6-8, 1989. Several hundred participants, ranging from high school seniors to university professors, from poets to ophthalmologists, came from sixteen states, the District of Columbia, and two foreign countriesFrance and Austria.

The attendees enjoyed major addresses by Emily Toth of Louisiana State University; Sandra Gilbert and Susan Gubar of Princeton University and Indiana University respectively; and John Carlos Rowe of the University of California, Irvine. They also heard panels of papers by lesser scholars, the first public reading of a dramatization by Sallie Bingham of Chopin's The Awakening, and a pedagogical session, "Chopin in the Classroom." Films of Chopin's fiction were screened. And most of the participants visited Chopin's former home, the Bayou Folk Museum, and Melrose Plantation, another local site of literary interest.

The Chopin conference was followed by a successful planning grant proposal to the National Endowment for the Humanities for a reading/ discussion project also focusing on Kate Chopin and publication of the Chopin conference papers. The preliminary work and research has been accomplished to support humanities scholars from Northwestern, the Scholars' College and the Louisiana School for Math, Science and the Arts who will lead a series of six programs in twelve parish libraries. The programs will be enhanced by a photographic exhibition of Chopin items and scenes from the archives of Watson Library, the Missouri Historical Society, and the Bayou Folk Museum.

The book of essays from the first Chopin conference was published in May 1990 by the NSU Press. NEH has now funded the implementation phase of "Kate Chopin: A Woman of Yesterday, Today and
Tomorrow," and the programs will occur in the fall of 1990 and the spring of 1991. (This project can be repeated in other locations, as the materials will be available for loan.)

Another unusual activity is Watson Library's Career Evaluation and Information Center, now in its second year of support from the Job Training Partnership Act (JTPA). The original intent of this grant idea was to provide information on jobs and careers to a geographic area of high unemployment-Natchitoches Parish, 12.5\%; Red River Parish, 13.9\%; and Sabine Parish, 11.9\% in February 1989 - and thereby supplement funds for Watson Library materials. ${ }^{2}$

Fleming Thomas, the Watson Library reference librarian who drew on his previous experience as a library director and academic dean at Burlington County College (N.J.), enlarged the goal of the project. Citing a U.S. Department of Labor statistic that over $60 \%$ of economically disadvantaged and displaced workers who complete JTPA training programs are able to enter the work force, Thomas chose to address the needs of the approximately $40 \%$ who still fail to achieve employment. ${ }^{3} \mathrm{He}$ designed a program to target the evaluative, counseling, psychological, motivational, and informational needs of the latter group. His plan was funded.

In early 1989 the Career Center began operation in Watson Library to service the needs of JTPA clients of Natchitoches Parish and the neighboring parishes of Red River and Sabine. Staffed by a psychometrician with a graduate degree in psychology and experience with psychological and vocational testing and counseling, an assistant psychometrician, and a secretary-the center began providing career evaluations, assisting in the development of career plans, and facilitating implementation of these plans.

Structured to address the regional unemployment problem, the JTPA-sponsored center, in full cooperation with local suppliers, tests and evaluates JTPA trainees and prepares a worker maturity profile on each, counsels with suppliers regarding the profile, advises training program graduates in reference to their needs, instructs in techniques of a successful job search, and makes available an extensive library of career materials. Through service as an information source, the staff also provides workshops to groups and/or organizations on ca-

${ }^{2}$ U.S. Bureau of Labor Statistics, "Unemployment in States and Local Areas, February, 1989," Employment and Unemployment in States and Local Areas (April 1989): 179-180.

${ }^{3}$ The Job Training Partnership Act (JTPA) Advisory Committee, Working Capital: JTPA Investments for the 90's (Washington: U.S. Dept. of Labor, March 1989), [12]. 
reers and conducts a lively program of interagency networking. Examples of the latter include referring clients to mental health agencies, vocational rehabilitation offices, legal services, training programs, and job opportunities.

The typical client of the Center is a school dropout. On the other hand, one was an internationally recognized scientist suffering from professional burnout. Many of the clients are adolescents; some are abused. Frequently they are single parents. Many have previously undiagnosed learning problems.

The Career Center proved so effective that the program was refunded in September 1989 and expanded from a service area of three parishes to ten. An additional psychologist was added to the staff, and a branch office was opened on another university campus.

One of the unquestionable factors in Louisiana's unemployment problem and the related lack of economic development is illiteracy. According to the Louisiana Literacy Task Force, "The National Center for Education Statistics estimates that 16\% of the adults in Louisiana-one in every six-are unable to read or write at any level."4 Watson Library's next successful grant proposal was to the U.S. Department of Education Student Literacy Corps Program. A proposal entitled "Teaching Social Responsibility Through Community Service," also designed by Fleming Thomas, has been funded to begin operation in the fall of 1990 .

Essentially, the program will use university students (preferably education majors) to tutor the educationally disadvantaged in local vocational schools, elementary schools, and several social service agencies. The tutors, who will receive academic credit for their efforts, will be supervised by Northwestern faculty members; and the academics will be organized and coordinated by the Coordinator of the Career Center.

Watson Library's newest projected service has four major goals: the encouragement of the concept of community service to the less fortunate; the increased success of local instructional programs by the provision of tutoring services; practical experience for university students who plan to teach; and enhancement of the University's image by providing more than a payroll for the community. Although not yet underway, the project has already attracted the additional volunteer services of an organization of retired teachers.

Obtaining funds for a humanities conference, administering the meeting, generating financial support for scholarly research and publishing,

${ }^{4}$ Louisiana Literacy Task Force, A Literate Louisiana: The Key to Economic Recovery and Future Growth (Baton Rouge: Louisiana Literacy Task Force, 1989), [i]. providing cultural programming, addressing the needs of the unemployed, and helping to fight the problem of illiteracy. Are these "unusual" services for an academic library? Perhaps. They certainly are not the "usual" activities of such an institution.

These activities have come into being in Watson Library, however, because the librarians of Northwestern State University of Louisiana share several strong beliefs:

- that librarians, as academic generalists, are highly informed;

- that librarians, in general, are creative, capable, and highly energetic;

- that academic librarians should be contributing citizens to the intellectual life of both the university and the surrounding community;

- that the management theory of job enrichment encourages us to try almost anything;

- and that our mandate to "serve the public" permits and even enables a range of library services that is practically unlimited.

Good ideas are usually well-received by responsible executive management. Fortunately, librarians at Northwestern serve with enlightened administrators who recognize and encourage originality.

\section{New Fulbright Award}

CIES has recently received word from the Fulbright Commission in London that there will be a Fulbright award for an archivist in the United Kingdom during the 1991-92 year. This is a new Fulbright award for an Archivist to research and develop the Memorial Library, 2nd Air Division (8th Air Force), Norwich, Norfolk, England. Applications will be accepted from individuals working as archivists in public libraries, college or university libraries, or major research libraries outside American higher education. Applicants should have specialized training in archive work, a minimum of three years of library experience as well as excellent communication skills, should be enthusiastic about American cultural activities, and be able to travel to give presentations.

The Memorial Library is a collection of books, records, and wartime memorabilia relating to over 6,400 American airmen based in the Norfolk and Suffolk area who were killed in action between 1939-1945.

The award is for $£ 15,500$ plus $£ 4,500$ expatriation allowance and travel for the grantee and one dependent. The award is for 12 months, October 1991-October 1992, though some flexibility exists for a 9-12 month appointment. Application deadline: February 1, 1991. For information contact: Karen Adams, CIES, (202) 686-6245. 